\title{
aThe Enthusiasm of Nahdlatul Ulama and Muhammadiyah Ideology in the Perspective of Post- Modern Ethics
}

\author{
U F Thohir ${ }^{1}$ \\ Institut Ilmu Keislaman Zainul Hasan Genggong, Probolinggo, Indonesia ${ }^{1}$ \\ \{umar.faruq.thohir@gmail.com ${ }^{1}$ \}
}

\begin{abstract}
Post-modernism perceives social phenomena through three fundamental structures, (1) deconstructionism, (2) relativism, and (3) pluralism. As one of the social symptoms of humanity, the religious movements of NU and Muhammadiyah also experienced a different development of thought from the beginning of its establishment. NU was established to provide "accompaniment" to the periphery Muslims of Indonesia, initially tending to be traditionaldecentralized, but ultimately also accepting modernist-centralistic principles. Likewise, Muhammadiyah, with its modernist slogan of purification, initially rejected tradition (local Islam), but ultimately also appreciated the cultural values that developed in the community. It figures out that in both bodies (NU and Muhammadiyah) there is a dynamic of thought that continues to evolve along with the desired model of da'wah in its time. This certainly will give a different impression with decades ago, where both were founded. This situation is in accordance with the three main principles of post-modernism, i.e. deconstructionism, relativism, and pluralism.
\end{abstract}

Keywords: Nahdhatul Ulama, Muhammadiyah, Post-modern Ethics

\section{Introduction}

The world of thought is usually faced with two dichotomous camps, i.e. traditionalism and modernism. They related to religious and socio-cultural thinking. Traditionalism is identified with conservative, closed, cultural attitudes and religious thoughts lacks respect for time, lacks program planning, looks back, believes in takhayyul, is slow in anticipating change, and so on [1]. Meanwhile, modernism is identified with a progressive attitude, is open, appreciates time, has a mature program planning, looks forward, quickly anticipates change, and so on. There is an impression, as if traditionalism is a symbol of backwardness, while modernism symbolizes progress, without looking deeper, a philosophy that underlies traditionalism and modernism, even blind to the goodness of modernism and the weaknesses of modernism[2].

However, modernism, in addition to promising comfort and convenience in life, providing the advancement of science and technology, also has a negative impact to reach by the progress of science and technology itself. These negative impacts can be seen at least from the lifestyle of hedonism, consumerism, a material measure of life, moral erosion, excessive 
natural exploration which results in damage to the environment, even the world is now confused with industrial waste, including nuclear industrial waste that carries tensions between countries. In the economy, there are many gaps between developed and developing countries, the increasing problem of unemployment and poverty[3].

Meanwhile, in traditional societies, all religious community groups prioritize togetherness and hold firm to the religious and moral standards of society. They live in harmony with nature and economics.

Based on these two dichotomous thoughts, it seems that postmodernism is critical of modernism and traditionalism by looking at its positive and negative aspects [4]. This postmodernism mindset is deconstructive, relativistic, and pluralistic [5].

This style of thinking of postmodernism also inspired two Indonesian religious-cultural thoughts which tended to be different from those suggested at the beginning of its founding, namely Nahdlatul Ulama and Muhammadiyah. Actually, religious-cultural thought in Indonesia is very diverse, such as Front Pembela Islam, Laskar Jihad Ahlussunnah Waljamaah, Hizbut Tahrir, HAMMAS, Ikhwanul Muslimin, Majelis Mujahidin, Persatuan Pekerja Muslim Indonesia, Nahdlatul Ulama, and Muhammadiyah [6]. However, this paper will discuss only about Nahdlatul Ulama and Muhammadiyah, because apart from the two groups of religious cultural thought, the pattern of thought is still "inclined" as it once was, did not experience many changes since the beginning. Moreover, Nahdlatul Ulama and Muhammadiyah have experienced development which is certainly different from what was suggested at the beginning of its establishment, and this is certainly in line with the principles of post-modernism, one of which is deconstructive [5].

Muhammadiyah, which is known for its modern and centralistic style of thinking, has now begun to adopt the traditional thoughts of local culture [7]. Likewise, Nahdhatul Ulama, which was once famous for traditionalist-decentralization, has now begun to think of structuralformalistic interests that emphasize positivistic legitimacy which used to tend to be ignored $[8]$.

In the beginning, these two large Indonesian mass organizations tended not to get along well, but lately, there were often activities held by the collaboration committee of NU andMuhammadiyah. In the past, it seemed that the difference in thought patterns was not just regression, but contradictions, even symbols that triggered hostility. However, lately, a sense of tolerance is more visible from the relationship between the two who are increasingly harmonious. From these symptoms the question arises, what exactly is the post-modernism epistemology? What is meant by the NU and Muhammadiyah [9] movements? What is the background of thought that underlies these two religious-cultural movements in appreciating the values of postmodernism? Realizing this, the paper will be written to answer these questions.

\section{Method}

This article is library research which examines the thinking development of Nahdhatul Ulama and Muhammadiyah through several books explain both of them. The data sources in this library research are collected from the literature related to Nahdhatul Ulama' and Muhammadiyah. Then, the collected data is analyzed through the post-modern approach.

\section{Result and Discussion}

Post-Modern Ethics 
Post-modernism ethics [10] no longer sees social phenomena as traditionalists which tend to be conservative towards local cultural values or like modernists who always use positivistempirical glasses in viewing objects, but see social phenomena of the three fundamental structures, (1) deconstructionism, (2) relativism, and (3) pluralism, as depicted by M. Amin Abdullah [5].

Deconstruction as a fundamental structure of post-modernism is defined as a criticism of major theories or established cultures. Post-modernism sees the dominance of big theories to close the possibility of the emergence of other theories that may be able to help understand reality and solve problems. The claim of a standard methodology, standard, which cannot be contested, is what is opposed by people like Paul K. Feyerabend.

In line with Paul K. Feyerabend is Jacques Derrida who also has the idea of deconstruction. According to al-Fayyadl, deconstruction referred to by Derrida is a defense to the Other, to the other meaning of the text, and the logic of the game which is repressed by the power of authorship. In other words, deconstruction is a liberation. Deconstruction is not at all part of naive nihilism that always negates the truth. Deconstruction moves beyond both nihilism and traditional dogmatism. If one of the philosophical tasks is constructive, then the deconstruction reminds us that every construction cannot avoid the metaphorical and intellectual characters of language; in the end, the truth that is compiled cannot be single and remains so vulnerable (relative)[11].

As a simple example of deconstruction, Weber's grand theory, for example, is about the relationship between the Protestant ethic and the spirit of capitalism [12]. Can Max Weber's theory be used to explain a particular culture other than European culture? Among the scientists who believed in this was Robert Bellah who applied Weber's theory to see Japanese society. Bellah believes like Weber, there is a positive correlation between Buddhist ethics after the Meiji Restoration with the spirit of Japanese economy and modernism. But critically, postmodernism will re-question the validity of the theory, because Buddhist ethics in Japan are not the same as Buddhist ethics in Vietnam, Sri Lanka, Thailand or Cambodia[5].

Meanwhile, relativism as a fundamental structure of postmodernism considers cultural values to be local-relative, not absolute-universal, in a sense, cannot be harmonized like mathematical calculations. Habits that set in one particular place are difficult to be applied exactly as they were before. Thomas S. Kuhn was mentioned as a thinker prototype that broke the beliefs of scientists who were positivistic. The idea of positivism indeed underscores the validity of natural laws and universal social laws that can be built by ratios. But they do not see the historical factors that play a role in applying these universal laws. According to Immanuel Kant, there are universal values in the area of morality[13].

Ontologically, universal values that are universal-transcendental are believed not to recognize socio-cultural influences in which humans are raised [14]. But Kant's thinking was criticized by Hegel. Hegel emphasized the aspect of historicity rather than transcendentality. He considered Kant's thinking to be ahistorical formalistic[13].

The thought of relativism believes that socio-cultural factors greatly influence the values that develop in certain eras and regions. For example, to understanding crime (crime), intellectuals have formally the same common thread between one culture and another. However, in the aspect of historicity, the material form of a crime, between one and the other is very different. With these material differences, observers tend to see it relative[5].

Pluralism as a fundamental structure of postmodernism implies that it is very difficult to maintain a "single paradigm" in any discourse. Everything is diverse, everything needs to be understood and approached with a multidimensional approach [15]. 
The diversity of culture, religion, family, race, economy, social, ethnicity, education, science, military, nation, state, not to mention political aspirations, suggests their pluralistic faces. In this connection, the "single paradigm" as put forward by the modernist cultural approach, both in scientific and other aspects, has been questioned by the stakeholders of cultures outside modern culture [16], [17].

Therefore, the ethics of postmodernism are more critical in filling the negative values of traditionalism and modernism, giving freedom to differences, and not assuming a truth to be absolute, because everything can develop in different spaces and times.

\section{Indonesian Religious Culture Thought: NU and Muhammadiyah}

NU and Muhammadiyah are the two largest and most entrenched groups of religious cultural thought in Indonesia. These two major groups of religious cultural thought, NU and Muhammadiyah, both stood before Indonesia became independent and both contributed significantly to the realization of Indonesia's independence. NU is better known as the protector of the peripheral Islamic community and Muhammadiyah is closer to the urban community. The following is a more comprehensive explanation.

\section{Nahdlatul Ulama}

The backwardness both mentally and economically experienced by the Indonesian people, due to colonialism and the confines of tradition, has aroused the awareness of educated people to fight for the dignity of this nation, through the path of education and organization. The movement in 1908 was known as "National Awakening". The spirit of the resurrection continues to spread everywhere after the indigenous people are aware of the suffering and backwardness of other nations. In response, there are educational organizations and liberation [18].

The pesantren who have been staunch against colonialism responded to the national awakening by forming a movement organization, such as Nahdlatul Wathan (Awakening of the Motherland) in 1916. Then in 1918 Taswirul Afkar was established or also known as "Nahdlatul Fikri" (awakening of thought), as a vehicle of social and political education for the santri. From there, Nahdlatut Tujjar was established, (merchant movement). United was used as the basis to improve the people's economy. With the existence of Nahdlatut Tujjar, then Taswirul Afkar, besides appearing as a study group also became an educational institution that developed very rapidly and had branches in several cities.

After various embryonal and ad-hoc committees and various organizations emerged, then it was felt necessary to build a more inclusive and systematic organization. So after coordinating with several kyai, finally an agreement emerged to buildan organization called Nahdlatul Ulama (Awakening of Ulama) on 16 Rajab 1344 H (January 31, 1926). This organization is headed by K.H. Hasyim Asy'ari as Rais Akbar [19].

In order to confirm the basic principles of this organization, K.H. Hasyim As"ari formulated the book Qânûn Asâsî (basic principles), then also formulated the book I'tiqâd Ahl al-Sunnah Wa al-Jamâ'ah. The two books are embodied in the NU khittah, which is used as a basis and reference for NU citizens in thinking and acting in the social, religious and political fields [20].

NU adheres to the ideology of Ahlussunah waljama'ah, a mindset that takes the middle ground between extreme aqlî (rationalists) and the extreme naqlî (scripturalists). Therefore, 
the source of thought for NU is not only the Qur'an and Sunnah, but also uses the ability of reason by considering empirical reality. Such thinking was referred to by previous thinkers such as Abu Hasan al-Asy'ari and Abu Mansur al-Maturidzi in the field of theology. Then in the field of jurisprudence more likely to follow the sect of Imam Shafi'i and recognize three other schools, Imam Hanafi, Imam Maliki, and Imam Hanbali as illustrated in the 4-star NU symbol below. While in the field of Sufism, developed the method of al-Ghazali and Junaid al-Baghdadi, which integrated Sufism with the Shari'a[21].

The idea of returning to khittah in 1984 was an important moment to reinterpret the teachings of ahl al-sunnah wa al-jamâ'ah, and to reformulate the method of thinking, both in the fiqh and social fields, and to reformulate NU's relations with the state. The movement succeeded in reviving the passion of thought and social dynamics in NU [20].

\section{Muhammadiyah}

The Muhammadiyah organization was founded by K.H. Ahmad Dahlan in Kampung Kauman Yogyakarta on November 18, 1912 (8 Dzulhijjah 1330 H). Persyarikatan Muhammadiyah was established to support the efforts of K.H. Ahmad Dahlan in purifying Islamic teachings which are considered to be influenced by mystical matters. This activity initially also had a da'wah base for women and young people in the form of recitation of Sidrah al-Muntahâ. In addition, its role in education was manifested in the establishment of primary and secondary schools, known as the Muhammadiyah Hooge School and subsequently renamed the Muhammadiyah Kweek School, which is now known as the Mu'allimin Madrasah located in Patangpuluhan, Wirobrajan and Mu'allimaat Muhammadiyah in Suronatan, Yogyakarta)[22].

During K.H. Ahmad Dahlan leadership (1912-1923), the influence of Muhammadiyah was limited to residencies such as Yogyakarta, Surakarta, Pekalongan, and Pekajangan, Pekalongan area now. Besides Yogya, Muhammadiyah branches were established in these cities in 1922. In 1925, Haji Abdul Karim Amrullah (Hamka) took Muhammadiyah to West Sumatra by opening a branch in Sungai Batang, Agam. Within a relatively short time, the Muhammadiyah wave currents had spread throughout West Sumatra, and it was from this region that Muhammadiyah moved throughout Sumatra, Sulawesi, and Kalimantan. In 1938, Muhammadiyah had spread throughout Indonesia [23].

Muhammadiyah is a large Islamic organization in Indonesia. The name of this organization was taken from the name of the Prophet Muhammad, so that Muhammadiyah can also be known as people who are followers of the Prophet Muhammad.

The main objective of Muhammadiyah is to restore all deviations that occur in the process of proselytizing. This deviation often causes Islamic teachings to mingle with habits in certain areas for reasons of adaptation [24].

The Muhammadiyah movement characterized the spirit of building a more advanced and well-educated social system and education. Showing the teachings of Islam is not just a religion that is personal and static, but dynamic and domiciled as a system of human life in all its aspects.

In its formation, Muhammadiyah reflects a lot on the commands of the Qur'an, including:

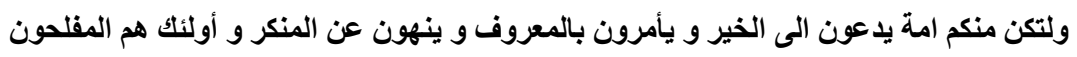

Meaning: And there must be among you a group of people who call for goodness, send to the Ma'ruf and prevent from the evil; they are lucky people. 
The verse, according to Muhammadiyah leaders, contains a signal for the movement of the people in carrying out Islamic $d a^{\prime}$ wah in an organized manner and also contains an affirmation of organizational life. So in the 6th point of the Muqaddimah of the Muhammadiyah's Articles of Association, it was stated, launching efforts and struggles with organizational order, which contained the importance of the organization as a necessary movement tool. As a positive impact of this organization, there are now many hospitals, orphanages, and educational places throughout Indonesia.

\section{Post-Modernism Ethics: Towards the New Face of Post-NU and Post-Muhammadiyah}

In the context of the Islamic belief system, in a certain period, a reformer must come to play a role in renewing this religion in terms of religious teaching and people's behavior. That is, the religious diversity of a people, may at some time experience ice, statism, conservatism, so that it requires continuous understanding again, so that religion remains dynamic, progressive and fresh. The religious reality of a people is essentially not influenced by the holy book, but also by several factors, namely: (1) The Scriptures that are believed, (2) The local culture in which the people are located, (3) The flow of accepted religious thought (Middle East, India, etc.), (4) The current (Western) thought of modernism, (5) political and economic [25].

The interaction of the five factors is the reality of diversity. Therefore there are many streams in Islam: Sunni, Mu'tazilah, Khawarij, Murjiah, Shia, etc. In Indonesia also known as secular Islam, abangan Islam, modernist Islam, traditionalist Islam, splinter Islam, and so on. The Sunnis were strongly influenced by the general flow of power at the time, while the Shiites were greatly influenced by fanaticism to Ali ibn Abi Talib and his descendants, the Mu'tazilah were strongly influenced by rationalism philosophy, while the Kharijites were influenced by their denial of Ali. Likewise, secular Islam is strongly influenced by the Western mind. Abangan Islam is strongly influenced by Javanese culture (kejawen). Traditionalist Islam is influenced by yellow book references, while modernist Islam is influenced by renewal movements in the Middle East, such as Muhammad Abduh and so on $[2]$.

The diverse flow of religious thought is now criticized and sued by postmodernism. The current religious thoughts which are today considered as established ones including Muhammadiyah which represents modernist Islam [26] and NU which represents the flow of traditionalist thinking. Nurcholis madjid in the seventies had tried to dismantle old paradigms that had been established, through his idea of secularization. Abdurrahman Wahid's statements and behavior also led to secularization [27]. Several speakers at the seminar on "Islam and NU-muhammadiyah Insights" have revealed how Islamic organizations have been trapped in two cultural camps that are equally detrimental to Islam, namely religion feudalism and religion bourgeoism [28].

According to Suminto A. Sayuti, in this contemporary era, more meaningful preaching must indeed be created and creatively designed, and prepared and intended for various segments of the ummah, the older generation, the younger generation, men and women, educated or less educated, and rural or urban communities. In this context, cultural propaganda will find its significance and relevance [29].

Now, in Indonesia, the flow of Islamic thought is enriched by the various publications by Shiite scholars from Iran, such as Ali Syariati, from India such as the work of Asghar Ali Engineer, and from Egypt like Hasan Hanafi. The books of their works are very different from 
the Islamic paradigm that has been understood by people in general, such as al-Dîn wa alTsaurah, the work of Hasan Hanafi, and so on [30].

The realm of postmodernism which tries to make claims and criticisms of traditionalism and modernism also influence the area of religious thought in Indonesia. It means that in religious thought there has been deconstruction, dismantling of existing religious thoughts, and relativizing every form of religious thought that has been deemed established [5].

Muhammadiyah and NU as agents of effective social reform bear a considerable psychohistorical burden, especially when both are trapped in the romanticism of history, boast of its historical role. As a result, both in their style of political articulation are expressive. During Orde Lama, Muhammadiyah was more radical and NU was more accommodating, and on the contrary now (the New Order and post-reformation), Muhammadiyah was accommodating and focused on routine, while NU was more radical and critical[9].

According to Dien Syamsuddin, the NU and Muhammadiyah movements can complement each other only if they get together to (1) reduce absolute religious understanding, (2) seek political education for Muhammadiyah and NU citizens, (3) realize periodic communication between the elites of the two organizations.

The principles of post-modernism ethics for these two religious-cultural thoughts (NU and Muhammadiyah) are solutions to communication between the two which tend to be less harmonious. Through the principle of relativism and pluralism, the supporters of these two movements can respect each other's differences and regard others as true based on their beliefs. Through the principle of deconstruction, the adherents of these two religious-cultural movements (NU-Muhammadiyah) are invited to always give criticism of all forms of "irregularities" even though they relate to something already established [21].

\section{Conclusion}

As one of the social symptoms of humanity, the religious movements of NU and Muhammadiyah also experienced a different development of thought since the beginning of its establishment. NU was established to provide "accompaniment" to the periphery Muslims of Indonesia, initially tending to be traditional-decentralized, but ultimately also accepting modernist-centralistic principles. Likewise Muhammadiyah, with its modernist slogan of purification, initially rejected tradition (local Islam), but ultimately also appreciated the cultural values that developed in the community.

It figures out that in both bodies (NU and Muhammadiyah) there is a dynamic of thought that continuously evolves along with the desired model of $d a^{\prime}$ wah in its time. This situation certainly will give a different impression of what happened decades ago when both were founded. This situation is in accordance with the three main principles of post-modernism, I .e.deconstructionism, relativism, and pluralism.

\section{References}
[1] M. M. Amin, Moralitas Pembangunan dalam Perspektif Agama-Agama di Indonesia. Yogyakarta: LPKSM, 1989.
[2] N. Al-Zastrouw, Gerakan Islam Simbolik: Politik Kepentingan FPI. Yogyakarta: LKiS, 2006.
[3] Soedjatmoko, Dimensi Spiritual dan Pembangunan di Indonesia. 
Yogyakarta: Muktamar NU, 1989.

[4] Kuntowijoyo, "Iman dan Kemajuan, Muhammadiyah dalam Persppektif sejarah," Menara, 1982.

[5] M. A. Abdullah, Falsafah Kalam di Era Post Modernisme. Yogyakarta: Pustaka Pelajar, 1997.

[6] K. Zada, Islam Radikal: Pergulatan Ormas-Ormas Islam Garis Keras Di Indonesia. Jakarta: Teraju, 2002.

[7] M. D. Rahardjo, Jabrohim, and S. Farid, "Muhammadiyah Sebagai Gerakan Seni dan Budaya: Suatu Warisan Intelektual yang Terlupakan," in Islam Jawa dan Dakwah Kultural, Yogyakarta: LPM Universitas Ahmad Dahlan, LSB PWM DIY and Pustaka Pelajar.

[8] M. van Bruinessen, B. Greg, and F. Geg, "Tradisonalisme Radikal Persinggungan Nahdlatul Ulama Negara," in Tradisi Menyongsong Masa Depan: Rekonstruksi Wacana Tradisionalis dalam NU, Yogyakarta: LKiS, 1997.

[9] D. Ilyas, Yunahar, Muhammadiyah dan NU: Reorientasi Wawasan Keislaman. Yogyakarta: LPPI UMY, LKPSM NU, dan PP Al-Muhsin Yogyakarta, 1994.

[10] S. Syukur, Etika Religius. Yogyakarta: Pustaka Pelaja, 2004.

[11] M. Fayyadl al-, Derrida. Yogyakarta: LKiS, 2005.

[12] D. Abercrombie, Nicholas and D. Desi Noviyani, Kamus Sosiologi. Yogyakarta: Pustaka Pelajar, 2010.

[13] M. A. Abdullah, Sejarah Filsafat Barat dan Kaitannya dengan Kondisi Sosio-Politik dari Zaman Kuno hingga sekarang. Yogyakarta: Pustaka Pelajar, 2007.

[14] I. Kant, Critique of Practical Reason, trans. Lewis Whis White Beck, New York: Mamillan Publishing Company, 1985.

[15] M. A. Abdullah, "Keimanan Universal di Tengah Pluralisme Budaya: Tentang Klaim Kebenaran dan Masa Depan Ilmu Agama," J. Ulumul Qur'an, vol. IV, no. 1, 1993.

[16] J. L. Esposito, The Islamic Threat Myth or Reality? New York: Oxford University Press, 1992.

[17] W. Frank, "Contemporary Approaches to the Study of Religion," in The Study of Religion in a Global Context, Berlin: Mouton Publishers, 1984.

[18] G. Fealy and B. Greg, "Tradisonalisme Radikal Persinggungan Nahdlatul Ulama Negara," in Wahab Chasbullah, Tradisionalisme dan Perkembangan Politik NU, Yogyakarta: LKiS, 1997.

[19] M. van Bruinessen, NU: Tradisi, Relasi-Relasi Kuasa, Pencarian Wacana Baru. Yogyakarta: LKiS, 1994.

[20] M. Nakamura, B. Greg, and F. Geg, "Tradisonalisme Radikal 
Persinggungan Nahdlatul Ulama Negara," in Krisis Kepemimpinan NU dan Pencarian Identitas Awal 1980-an: Dari Muktamar semarang 1979 hingga Muktamar Situbondo 1984, Yogyakarta: LKiS, 1979, p. 19.

[21] L. Ida, NU Muda: Kaum Progresif dan Sekularisme Baru. Jakarta: Erlangga, 2004.

[22] A. M. Mulkhan, Jabrohim, and F. Setiawan, "Muhammadiyah Sebagai Gerakan Seni dan Budaya: Suatu Warisan Intelektual yang Terlupakan," in Dakwah Kultural: Strategi Perubahan Berbasis Tradisi Lokal, Yogyakarta: LPM Universitas Ahmad Dahlan, LS, 2009.

[23] Muarif, Jabrohim, and F. (ed. . Setiawan, "Muhammadiyah Sebagai Gerakan Seni dan Budaya: Suatu Warisan Intelektual yang Terlupakan," in Dakwah Kultural: Mencermati Kearifan Dakwah Muhammadiyah, Yogyakarta: LPM Universitas Ahmad Dahlan, LSB PWM DIY, 2009.

[24] M. R. Hafidz al-, Jabrohim, and F. Setiawan, "Muhammadiyah Sebagai Gerakan Seni dan Budaya: Suatu Warisan Intelektual yang Terlupakan," in Pokok-Pokok Pikiran Majelis Tarjih tentang Islam dan Kebudayaan, Yogyakarta: LPM Universitas Ahmad Dahlan.

[25] H. Ahmad, Pengantar Teologi Islam. Jakarta: Penerbit Pustaka AlHusna, 1980.

[26] M. A. Abdullah, M. Azhar, and H. Ilyas, "Pengembangan Pemikiran Keislaman Muhammadiyah: Purifikasi dan Dinamisasi," in Sambutan Ketua Majlis Tarjih dan Pengembangan Pemikiran Islam Pimpinan Pusat Muhammadiyah, Yogyakarta: Pustaka Pelajar, 2000, p. 20.

[27] H. M. Rasjidi, Koreksi terhadap Nurcholis Madjid tentang Sekularisasi. Jakarta: Bulan Bintang, 1972.

[28] M. F. Mas'udi and Yunahar Ilyas, "Muhammadiyah NU, Reorientasi Wawasan Keislaman," in Menuju Keberagamaan yang Populistik, Reorientasi Pemikiran keagamaan NU-Muhammadiyah, 1993.

[29] S. A. Sayuti and Jabrohim, "Dakwah Kultural: Bukan Dakwah tentang Budaya, tetapi...," in Muhammadiyah:Gerakan Kebudayaan yang Berkemajuan, Yogyakarta: Pustaka Pelajar, 2010.

[30] M. A. Abdullah and A. K. Soleh, "Wacana Baru Filsafat Islam," in Filsafat Islam bukan hanya Sejarah Pemikiran, Yogyakarta: Pustaka Pelajar, 2004. 